\title{
THE DISTRIBUTION AND POTENTIAL PROBLEMS OF MIMOSA PIGRA L. IN INDONESIA
}

\author{
SRI S. TJITROSOEDIRDJO \\ Tropical Agricultural Pest Biology Program, BIOTROP, Bogor, Indonesia
}

\begin{abstract}
Mimosa pigra L. (Mimosa asperata L.) of the family Mimosaceae is an introduced species from South America which is locally naturalized in Indonesia.

The present known distribution sites are still restricted to Java, Sumatra, and Kalimantan. It is found in almost all provinces of Java and many heavily infested areas have been noted in Jakarta and West Java. The introduction of the plant to other islands has not been reported yet. The separation of the islands by sea is preventing the further spread of the plant in Indonesia.

Control is basically occasional and on an individual basis. There is no sustained effort yet to control the plant. The urgency of controlling and restricting its spread cannot be over emphasized.
\end{abstract}

\section{INTRODUCTION}

Mimosa pigra L. is an introduced species in Indonesia from South America which has been locally naturalized for a long time (Backer and van den Brink 1963). Soerjani (1979) included this species as one of the ten serious aquatic weeds in Indonesia. The plant is very difficult to control because its spiny and woody character makes it very difficult to penetrate when growing very densely.

Recently, there is a large number of areas in Jakarta and its vicinity, as well as some areas in West Java infested with $M$. pigra.

In Thailand, M. pigra was introduced from Indonesia in 1947. It was first planted in Amphus Mae Taeng where it was used as a ground cover to improve soil quality and to help prevent bank erosion. Within 30 years, it has infested large areas of Northern Thailand (Lamar Robert 1982).

Among the Institutes working on M. Pigra in Indonesia are: the Central Research Institute for Plantation which conducted the study on its biology and ecology (Sumaryono and Soedarsan 1983); the Biological Research and Development Center, Indonesian Institute of Sciences, which conducted studies on its ecology, biological control and taxonomic aspects (Uji 1988, Partomihardjo 1988, and Kahono 1988); and BIOTROP which studied its potential problems at Bening and Saradan Reservoir, East Java (Anonymous 1983). Research on the biology, distribution, ecological role in the environment and control methods in Indonesia should be intensified and the problem must be dealt with before it expands to larger areas and become more serious. 
The distribution and potential problems of Mimosa pigra L. -Sri S. Tjitrosoedirdjo

In this paper, the present distribution of M. pigra at the known sites and the potential problems in the future are discussed and evaluated.

\section{DISTRIBUTION OF MIMOSA PIGRA IN INDONESIA}

The distribution of M. pigra in Indonesia was obtained from the examination of herbarium specimens at the Herbarium Bogoriense, Bogor, Indonesia and information from several other sources (Soedarsan 1980, Sumaryono and Soedarsan 1983).

Mimosa pigra was first introduced to Indonesia by the Bogor Botanical Garden from Mexico (Thysmann and Binnendijk 1866). The earliest record of its presence was in 1844 from Bogor, West Java (Hasskarl 1844).

The oldest existing herbarium specimens were found in 1902 from Ciliwung riverside in Bogor identified as Mimosa asperata L.; in the same year, a specimen was also found in Jakarta.

The present distribution of M. pigra in Indonesia is still restricted to Java, Sumatra and Kalimantan (Figure 1). Most of the specimens were found in Java, i.e. from all the provinces, Jakarta, West Java, Central Java and East Java.

In Sumatra it was reported from Solok, West Sumatra (Soedarsan 1980) and Sibolangit, North Sumatra in 1917.

The only specimen from Kalimantan was found in Samarinda in 1979. It seems that in Kalimantan M. pigra was newly introduced. There is no report yet from other islands.

According to the recent information in Indonesia there are two types of the habits of M. pigra i.e. erect and prostrate stenis. Field observations showed different morphological characteristics of the two types of M. pigra. The prostrate stem type is only strictly distributed around Jakarta, Bogor, Tangerang and Bekasi at an altitude of 5-260 $\mathrm{m}$ a.s.l. The erect stem type is widely distributed all over Java (Partomihardjo 1988, Uji 1988).

Backer and van den Brink (1963) indicated that in Indonesia it can be found at an altitude of 1-700 $\mathrm{m}$ above sea level.

In different places $M$. pigra is called by different names such as klampis air, putri main hitam (Sumaryono and Soedarsan 1983) andputri malu raksasa. In West Java it is known as jerujut, gehgeran and cucuk buset, Rondo kaget (Sunda), pis kucing (Java). 
BIOTROPIA No. 2, 1988/1989

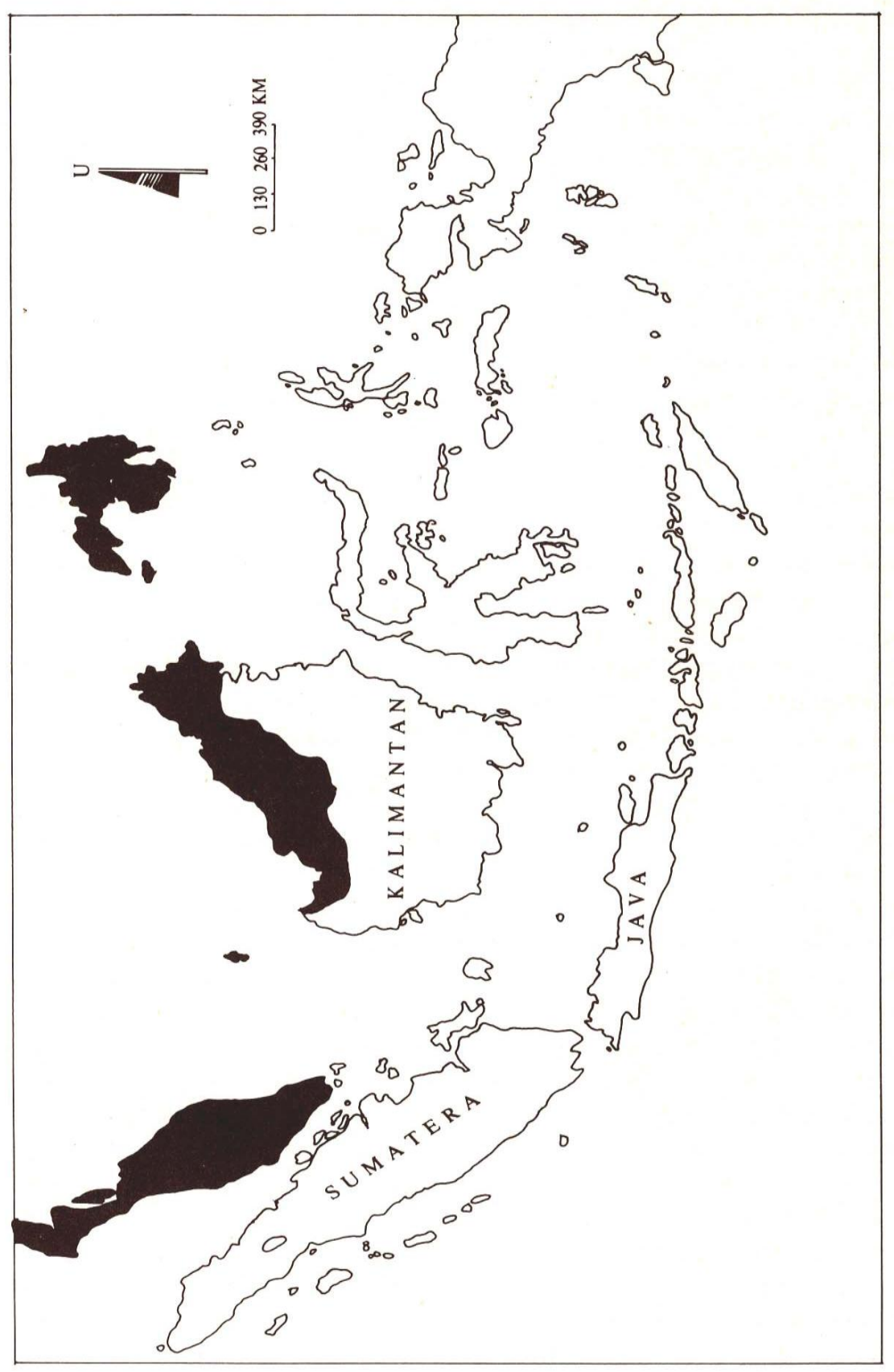




\section{POTENTIAL PROBLEMS IN THE FUTURE}

There are some factors assisting the dispersal and rapid colonization of $M$. pigra (Miller 1982). Among them are the intrinsic characteristics of the plant, like the ability of whole seed pods on their segments to float on water for long periods, and the hairy nature of pods allowing segments to stick to hair or clothing, which enable them to spread easily. This is combined with dispersal both by natural uncontrollable forces and by man as well as animals.

In a river, the spread of M. pigra downstream from its original location has been largely through uncontrollable water movement. Its spread to isolated sites away from the river is mainly by human activity through removal of sand from the river for use in construction of roads or buildings.

The ability of M. pigra to rapidly colonize areas is due to its inherent ability to flower and seed all year round under favorable conditions, the production of large quantities of seeds, their long term viability and tolerance to both flood and drought.

Wanichanantakul and Chinawong (1979) reported that in Thailand, an average plant is seeded twelve times per year. They also found that prolonged seed dormancy was due to the hard seed coat.

In Indonesia, (Anonymous 1983) the rate of growth of M. pigra at Bening and Saradan reservoirs, East Java, was observed. The rate of growth was $11.54 \mathrm{~g}$ dry weight $/ \mathrm{day}^{-1}$ or $4.42 \% \mathrm{day}^{-1}$. Although it is less than the rate of growth of the floating aquatic weeds, it is relatively high for a woody perennial plant. The high rate of growth is also supported by the high production of viable seeds.

The number of mature seeds found in $5 \mathrm{~cm}$ depth of soil in a plot $25 \times 25 \mathrm{~cm}^{2}$ was 200 .

The laboratory experiments showed that the seed germination rate was very high, i.e. approximately $93.5 \%$ under light and $89.5 \%$ under dark conditions (Anonymous 1983).

Sumaryono and Soedarsan, 1983 reported that in Bogor, the stem diameter reached up to $4.6 \mathrm{~cm}$ after 8 months. The first flowers appeared 4 months after seed germination. They also reported that after cutting, regeneration is very rapid. It grew better in a soil water of $43-67 \%$ and the plant could survive in flooded land although its growth was retarded.

In Java, M. pigra has spread faster than on other islands. Colonization by $M$. pigra is basically through movement of seeds by water. Mostly, the plants were found in wet places-such as riverside, irrigation canal or at the shore of the lake (Table 1). Introduction to isolated places not reached by water can also be noticed. It is also found along the road, railway or in waste lands. 
BIOTROPIA No. 2, 1988/1989

Table 1. Distribution of M. pigra in Indonesia based on the herbarium specimens at the Herbarium Bogoriense", other sources (Soedarsan $1980^{2)}$ ), Anon, 1983³), and own observation ${ }^{4}$.

\begin{tabular}{|c|c|c|c|c|}
\hline Island & Provinces & Locations & Altitude & Habitat \\
\hline \multirow[t]{20}{*}{ Java } & \multirow[t]{10}{*}{ West Java } & Jabaru, Bogor ${ }^{1)}$ & 260 & $\begin{array}{l}\text { Embankments in } \\
\text { rice field }\end{array}$ \\
\hline & & $\begin{array}{l}\text { Ciliwung river } \\
\text { Bogor }^{1)}\end{array}$ & 360 & Riverside \\
\hline & & $\begin{array}{l}\text { Forest Reserve } \\
\text { North of Jasinga }{ }^{1)}\end{array}$ & 90 & - \\
\hline & & Depok, Bogor ${ }^{1)}$ & 100 & Wayside \\
\hline & & Buahbatu, Bandung ${ }^{1)}$ & 700 & Wet places \\
\hline & & $\begin{array}{l}\text { Rawa Tembaga, } \\
\text { between Kranji-Bekasi }{ }^{1)}\end{array}$ & 20 & Swampy area \\
\hline & & $\begin{array}{l}\text { Haurgeulis, } \\
\text { Indramayu }^{1)}\end{array}$ & 25 & Railway side \\
\hline & & Tangerang ${ }^{1)}$ & 18 & Riverside \\
\hline & & Citeras, Banten ${ }^{1)}$ & 40 & $\begin{array}{l}\text { Along the } \\
\text { irrigation canal }\end{array}$ \\
\hline & & $\begin{array}{l}\text { Lebakbolang, } \\
\text { Rangkasbitung }\end{array}$ & 15 & Riverside \\
\hline & \multirow[t]{5}{*}{ Jakarta } & Tanjung Priok ${ }^{1)}$ & 5 & Along the canal \\
\hline & & Kali Sunter ${ }^{1)}$ & 5 & Riverside \\
\hline & & Jagorawi highway4) $^{4}$ & - & $\begin{array}{l}\text { Along the highway } \\
\text { Bogor - Jakarta }\end{array}$ \\
\hline & & Jabotabek area ${ }^{4)}$ & - & $\begin{array}{l}\text { Along the rail-way } \\
\text { Bogor-Jakarta }\end{array}$ \\
\hline & & $\begin{array}{l}\text { Cengkareng } \\
\text { highway }{ }^{4}\end{array}$ & - & $\begin{array}{l}\text { Along the high } \\
\text { way to Soekarno-Hatta } \\
\text { airport }\end{array}$ \\
\hline & Yogyakarta & Yogyakarta $^{4)}$ & 113 & Wayside \\
\hline & \multirow[t]{2}{*}{$\begin{array}{l}\text { Central } \\
\text { Java }\end{array}$} & $\begin{array}{l}\text { Mertoyudan, } \\
\text { Magelang }\end{array}$ & - & Wayside \\
\hline & & Magelang ${ }^{4)}$ & 380 & Wayside \\
\hline & \multirow[t]{2}{*}{ East Java } & Bening reservoir ${ }^{3)}$ & - & Lake shore \\
\hline & & Saradan reservoir ${ }^{3)}$ & - & Lake shore \\
\hline \multirow[t]{3}{*}{ Sumatra } & $\begin{array}{l}\text { North } \\
\text { Sumatra }\end{array}$ & Sibolangit ${ }^{1)}$ & 500 & - \\
\hline & $\begin{array}{l}\text { West } \\
\text { Sumatra }\end{array}$ & Solok $^{2)}$ & 400 & Riverside \\
\hline & $\begin{array}{l}\text { East } \\
\text { Kalimantan }\end{array}$ & $\begin{array}{l}\text { between Samarinda } \\
\text { and Tenggarong }{ }^{1)}\end{array}$ & - & Wayside \\
\hline
\end{tabular}


Increasing development of housing, industrial estates, highways, airports, bridges and roads in Jakarta use large amount of sand. This sand comes from the rivers or places already contaminated by M. pigra seeds. Heavy infestation can be found in waste lands close to housing and industrial estates, along the Jagorawi highway, and along the way to Soekarno-Hatta airport.

At Ciapus Bogor, there is a big sand quarry where the product is distributed mostly to Jakarta and West Java. M. pigra can be found easily in the areas surrounding the quarry. This condition contributes to the further spread of M. pigra elsewhere.

In Central Java, M. pigra can be found at the roadside between Yogyakarta and Magelang. There are some rivers such as Krasak, Putih and Blongkeng, between these two cities. The rivers are rich in sand from Merapi mountain, which is collected and distributed to many places in Central Java. If the sand from these rivers is contaminated with $M$. pigra seeds, it can be spread further within a short time.

Anonymous (1983) reported that in East Java, Bening and Saradan reservoirs are infested with M. pigra. The plants are mostly found at the lake shore. At Saradan reservoir M. pigra is a dominant species.

At Bening reservoir where the fluctuation of the water is very high (approximately $13 \mathrm{~m}), M$. pigra appears to be particularly well adapted to grow in a seasonally flooded habitat. During the dry season, $M$. pigra grows well and biomass production is very high. During this time at Bening reservoir, the flooded area is 570 ha and there are 370 ha which can be potentially colonized by M. pigra. After flooding during the wet season, $M$. pigra will decompose and the nutrients released would enrich the water. Its decay will cause an increase in the water's carbon dioxide content, chemical oxygen demand, ammonia and nitrate, and nitrogen, and reduce its $\mathrm{pH}$ and dissolved oxygen concentration. The plants recover by germination of viable seeds.

Anonymous (1983) suggested that a control program should be carried out during the dry season before flowering, to prevent the production of seeds.

In Sumatra, Soedarsan (1980) reported that M. pigra was found close to the river. It reached $4 \mathrm{~m}$ in height. If there is no control treatment M. pigra will spread further.

With the construction of the Trans Sumatra highway from Aceh to Java and crossing the Sunda Channel, there is a possibility that M. pigra will be spread from Java to Sumatra through the movement of man and vehicles. 


\section{SUMMARY}

Although $M$. pigra has been introduced in Indonesia for a long time, the existing known places are still restricted to Java, Sumatra and Kalimantan. The introduction of the plant to other islands has not been reported yet. The separation of the islands by the sea is preventing the further spread of the plant in Indonesia.

In Java, M. pigra is widely distributed, it is found in almost all provinces. The high rate of growth, the ability of producing large amounts of seed, the great regenerative power and also the resistance to flood and drought support the rapid colonization of $M$. pigra.

In Jakarta and West Java, many places have been infested heavily by $M$. pigra. There is no sustained effort yet to control the plant, only occasionally by individual initiative.

The urgency of controlling and restricting its spread cannot be over emphasized.

\section{REFERENCES}

ANONYMOUS. 1983. Penyelidikan Tanaman Air dan Perikanan Waduk pada Proyek Irigasi Widas (Studies on the Reservoir's Aquatic Weeds and Fishery at the Widas Irrigation). Internal Report BIOTROP, Bogor, Indonesia.

BACKER, C.A. and R.C.B. VANDER BRINK. 1963. Flora of Java. Vol. I. N.V.P. Noordhof-Groningen-

The Netherlands.

LAMAR ROBERT, G. 1982. Economic Returns to Investment in Control of M. pigra in Thailand. IPPC Document No. 42. A-82. MPC Agricultural Economics Report No. 15.

HASSKARL, J.K. 1844. Catalogus Plantarum in Horto Botanico Bogoriense Cultarum Alter. (Ter Lands-Drukkerij : Batavia).

MILLER, I.L. 1982. The Distribution and Threat of M. pigra in Australia Proc. International Symposium on $M$. pigra Management Chiang Mai, Thailand.

PARTOMIHARDJO, T. 1988. Studies on the biology of Mimosa pigra for supporting its control in Indonesia. Proceeding WSSI Conference Vol. II.

SOEDARSAn, A. 1980. Potensi Klampis Air (M. pigra L.). Sebagai Gulma di Masa Depan (The Potential of M. pigra as a weed in the Future). Menara Perkebunan 48(6): 179-180.

SOERJANI, M. 1979. Recent Trends in Aquatic Weed Management in Indonesia Proc. 7th Asian Pac. Weed Sci. Conf. Sydney, Australia. Supp. Vol.

SUMARYONOand SOEDARSAN, A. 1983. Beberapa aspek pertumbuhan klampis air (Some aspect of the growth of M. pigra). Menara Perkebunan 51 (6): 160-164

. THYSMANN, J.E. and S. BINNENDIJK. 1866. Catalogus Plantarum quae in Horto Botanico Bogoriense Colunter-Ter Lands - Drukkerij: Batavia.

Uji, T. 1988. Mimosa species in Java. Proceeding Indonesian Weed Science Society Conf. Vol. I.

WANICHANANTAKUL, P. and S. CHINAWONO. 1979. Some aspects on the biology on M. pigra in

Northern Thailand. Proc. 7th Asian Pac. Weed Sci. Soc. Conf., Sydney, Australia. 